create structured exchanges of experiences and to build up a knowledge base which can provide pragmatic data relevant for local as well as European policy.

The approach of the CLIP project envisions a focus on the research demand and its practical relevance at the municipal level, involving the partner cities as subjects and actors in the research process. The research institutions are primarily responsible for facilitating the research, ensuring standards of scientific quality and linking these activities to the European level by ensuring the comparability of the project's activities. Thus, the project has its centres of gravity at the local municipal level and at the European level, mediated and facilitated by the research institutions.

The bottom-up generation of research questions which are structured and adapted for comparability by experienced research institutions supports a high relevance of the results for practice and policy making; the dissemination is built into in the research process and relies on existing networks at various levels. The cooperation between the local municipalities and the facilitating research institutions allows for good access to the field and to relevant data, and enables the project to build expert validity also from municipal experts.

\title{
2 Policy context at the European level
}

According to the treaties, the EU has no legal authority over local housing policy. However, housing has been a subject of discussion at the EU level for many years. Several political initiatives have been undertaken by important institutions at the European level. Although most of these statements refer to social inclusion, housing conditions and urban development without referring explicitly to the integration of migrants in the urban context, more recent statements can be found on this more specific aspect.

\subsection{The European Parliament}

A recent publication of the EP Committee of Civil Liberties, Justice and Home Affairs - Report on strategies and means for the integration of immigrants in the European Union - [2006/2056(INI)] is relevant for the CLIP project. This motion for an EP resolution states that, "local, regional and national authorities play an essential role and [...] their responsibilities in areas such as town planning, housing and education have a direct impact on the integration process" [2006/2056(INI), point G, p. 22]. It further states that:

"[...] the Union has [...] long been paralysed by the widely circulated idea that 'integration is local'. Integration initiatives are indeed implemented locally. [...] But integration is global in its implications - especially when it fails. Thus, while local, regional, and national authorities should determine the precise integration measures implemented, Member States must pursue ef- 
fective integration strategies whose outcomes advance the Union's common interests. It is in monitoring these outcomes where EU institutions can and must become far more active and - particularly - effective” (ibid, p. 13).

The European Parliament's URBAN-Housing Intergroup adopted a European Charter on Housing on April 26, 2006. Housing is not a European Union responsibility in the strict sense, but policies developed and supported by the European Union do have an impact. The Charter calls for Structural Fund eligibility for the renovation of social housing and the content of the Charter will now be discussed by the European Parliament's Regional Policy Committee.

The Charter highlights the importance of implementing fundamental social rights such as the right to worthy, decent and affordable housing. The text goes on to say that access to housing represents a crucial step in combating poverty, particularly in cities, and in pursuing the objective of social inclusion of vulnerable individuals deprived of decent housing:

"Housing should be integrated into the economic, social and territorial cohesion policy of the European Union respecting the European Union and the Member States jurisdictions, as well as the subsidiarity and additionality principles. In that capacity, expenditure in terms of renewal of vocational social housing, with a view to saving energy, meeting the social cohesion objective and protecting environment in the sustainable urban development context and the global quality of the citizens' environment, should be eligible to the Structural Funds". (Article 7, § 1).

"The European social inclusion strategy should be fully integrated in the Community policies. The role of housing must be recognised thereto as it deserves. [...] the European Union should promote the exchange of good practices in terms of effective implementation of the right to housing” (Article $8, \S 1$ ).

\subsection{The European Commission}

Although the European Commission has no specific Directorate General on housing issues, they have been addressed by three DG's (mainly in the contexts of social integration, anti-discrimination and integration of migrants).

Access to decent and affordable housing is an important dimension of the social inclusion strategy of the European Union and the related National Action Plans (NAPs) on social inclusion. In 1997 the EU Member States approved the Treaty of Amsterdam. Article 13 of this Treaty granted the Community new powers to combat discrimination on the grounds of sex, racial or ethnic origin, religion or belief, disability, age or sexual orientation. Since the Treaty of Amsterdam came into force in 1999, new EC laws (or Directives) that have been enacted in the area of anti-discrimination are the Racial Equality Directive, 2000/43/EC, and the Employment Equality Directive, 2000/78/EC. The Racial Equality Directive implemented the principle of equal treatment between persons irrespective of racial or ethnic origin and Employ- 
ment Equality Directive established a general framework for equal treatment in employment and occupation.

In March 2000, the European Council of Lisbon launched the EU strategy against poverty and social exclusion. The National Action Plans against poverty and social exclusion were initiated, with the following targets set for 2010: (a) facilitate participation in employment and access by all to resources, rights, goods and services, (b) prevent risks of exclusion, (c) help the most vulnerable, (d) mobilise all relevant bodies. The NAPs also have special regard for migrants. The NAPs of the EU member states were submitted to the EUC by July 2003 (see Combat Poverty Agency, 2003: 1 ff). Nevertheless, in most member states of the EU the National Action Plans (NAPs) on Social Inclusion either ignore the significance of the issue of housing or do not accord it a high priority.

With regard to social integration, the Nice European Council in December 2000 adopted common objectives in the fight against social exclusion and poverty, providing a definition of appropriate objectives as those which "implement policies which aim to provide access for all to decent and sanitary housing" [Definition of appropriate objectives, 1.2(b), p. 8]. In December 2002, these definitions were revised by the Employment, Social Policy, Health and Consumer Affairs Council. They amended, among others, point 3(a) on vulnerable groups and included in this group individuals who "belong to a group experiencing particular integration problems such as those affecting immigrants" [SOC 508, point 3(a), p. 12].

The Racial Equality Directive 2000/43/EC implemented

"the principle of equal treatment between people irrespective of racial or ethnic origin" and ensured "the development of democratic and tolerant societies which allow the participation of all persons irrespective of racial or ethnic origin, specific action in the field of discrimination based on racial or ethnic origin" and which "should go beyond access to employed and self-employed activities [...]."

In Article 3.1 it is continued that

"1. [...] this Directive shall apply to all persons, as regards both the public and private sectors, including public bodies, in relation to [...] access to and supply of goods and services which are available to the public, including housing." The Directive shall give "protection against discrimination in employment and training, education, social protection (including social security and healthcare), social advantages, membership and involvement in organisations of workers and employers. ,2

2 Council Directive 2000/43/EC of 29 June 2000 implementing the principle of equal treatment between persons irrespective of racial or ethnic origin. Official Journal L 180, 19/07/2000P.00220026 (http://ec.europa.eu/employment_social/fundamental_rights/legis/lgdirect_en.htm). 
The role of the city in these fields has been explicitly recognized in a recent proposal for a Council Decision on Community strategic guidelines on cohesion:

"A related, and highly important, factor determining the effectiveness of cohesion policy is the quality of the partnership between all stakeholders, including those at regional and local level, in the preparation and implementation of programmes" [COM(2006) 386 final, 11].

"Cities and metropolitan areas concentrate not only opportunities but also challenges and account should be taken of the specific problems facing urban areas, such as unemployment and social exclusion (including the problem of the 'working poor'), high and rising crime rates, increased congestion and the existence of pockets of deprivation within city boundaries. [...] In urban areas, the environmental, economic and social dimensions are strongly interlinked" (ibid, 33).

"Based on previous experience, there are a number of key principles in urban actions. First, the key partners in the cities and local authorities have an important role to play in achieving these objectives. As mentioned above, Member States may delegate responsibility to cities for urban development. This is particularly important where proximity matters, for example, in order to respond to the challenges of a mostly local nature such as social exclusion or lack of access to key services" (ibid, 34).

The communication "Cohesion Policy and cities: the urban contribution to growth and jobs in the regions" [COM (2006) 385 final] refers in chapter 6 to inequalities within the cities:

"The urban paradox is also reflected in disparities between neighbourhoods. The Urban Audit shows that almost all cities where unemployment is at a level of $10 \%$ or higher, have certain areas within which unemployment rates are at least double the city average. In some cases, unemployment rates reach up to 60\%. Within such deprived neighbourhoods, high unemployment is compounded by multiple deprivations in terms of poor housing, poor environment, poor health, poor education, few job opportunities and high crime rates" (ibid, p. 9).

It refers, however, not to housing aspects, but recommends

"actions for breaking-up of patterns of segregation and the integration of migrants, including language and more general training. It is essential to involve the target community in planning and providing such training” (ibid, p. 10).

\subsection{The Council of Ministers}

On 5 May, the Council of Ministers reached agreement on the European Structural Funds for the period 2007-2013. Funds for housing are provided to the new EU member states from the European Regional Development Fund (ERDF). To be eligible for ERDF funding for housing, spending must be in the context of an integrated 
urban development initiative or to upgrade rundown areas or areas threatened by social exclusion. The housing concerned must be multi-family housing designated for low-income families:

"Within the framework of an integrated urban development operation, it is considered necessary to support limited actions to renovate housing in areas experiencing or threatened by physical deterioration and social exclusion in the Member States that acceded to the European Union on or after 1 May 2004 (Article 5). It is necessary to establish that the contribution from the ERDF to housing expenditure should concern the provision of good quality accommodation for lower income groups, including recently privatised housing stock, as well as accommodation for vulnerable social groups" (Article 6).

\subsection{The EU Housing Ministers Working Group}

An informal working group of the Housing Ministers of the European Union meets annually. At these meetings, a broad scope of housing policies are discussed. Related to the integration of migrants, the working group addressed at its 2004 meeting, "Cities empower Europe," the issue of social integration in European cities:

"Ministers encourage greater integration of national policy sectors in affordable housing, health care, education, safety and employment to increase the impact of social inclusion policies. The contribution that cities make to social inclusion should be recognised and strengthened by national governments. Ministers acknowledge the need for compact cities with mixed uses in preventing urban sprawl, and reducing social segregation. They encourage Member States to emphasize in their National Action Plans on Social Inclusion the added value of the area-based integrated approach to deprived urban areas by local authorities" (Conclusions of the meeting, point 3.6).

At the following meeting in Prague in 2005, the working group supported the inclusion of housing issues into the structural funds and asked EU programmes to take housing issues into consideration. There was a meeting on October 16, 2006 in Barcelona.

\subsection{The Council of Europe}

The Committee of Ministers at the Council of Europe in Strasbourg adopted on September 22, 1988 a recommendation on migrants' housing [Council of Europe, Committee of Ministers, R (88) 14]. In this recommendation, the Committee of Ministers stated that "housing plays an important role in relations between migrants and the indigenous population" (ibid, point 2) and that "migrants are entitled to equality of treatment with the indigenous population in housing matters" (ibid, point 3). It referred to the relation between the housing situation for migrants and their general socio-economic status by stating that "improving migrants' housing conditions often depends on improving their socio-economic and cultural conditions" (ibid, point 6). It 
rejected "concepts such as 'tolerance threshold" " as being not appropriate to "solve problems arising when migrants and the indigenous population live in close proximity" (ibid, point 9). In the recommendation, the Committee of Ministers asked the Member States to "take account, when housing and town planning policies are being drawn up, of aspects of the social and cultural life of migrants which are conducive to their integration in the urban environment" (ibid, 14vii), and to "invite local authorities to seek the opinion of migrants' consultative organizations, where such bodies exist, whenever migrants' interests are affected" (ibid, 14xii).

On December 19 2001, the Group of Specialists on Housing Policies for Social Cohesion (CS-HO) within the Council of Ministers issued general principles for policies addressing access to housing for disadvantaged categories of persons [CM(2001)189 addendum 3]. The principles asked to "ensure the provision of affordable housing to disadvantaged categories of persons," and insisted that:

"the public authorities must create an appropriate legal framework for housing markets with regard to property rights, security of tenure and consumer protection, to make the necessary institutional arrangements, to adopt policies to expand the supply of affordable housing and provide better legal security of tenure and non-discriminatory access to housing for all" [ibid, Appendix I, point II, 7].

"The provision of housing for disadvantaged categories of persons requires action not only by public authorities at all levels, but by all sectors of society, including the private sector and non-governmental organisations, as well as by partner organisations and entities of the international community. Disadvantaged categories of persons themselves and civil society organisations should be enabled to play a proactive role through agenda-setting participatory mechanisms" [ibid, Appendix I, point II, 8].

"There is a strong interdependence between housing policy and other policies concerning access to social rights such as social protection, employment, health, and education" (ibid, Appendix I, point II, 10).

The recommendations also considered the role of the cities:

"Within a national housing policy framework which provides, inter alia, for the necessary allocation of resources required by local authorities to fulfil their functions, there should be a significant degree of local autonomy and participation in decision-making, implementation, and resource mobilisation and use. The role and responsibilities of local authorities and civil society organisations in housing policy and the distribution of tasks between them should be clearly and legally defined" (ibid, Appendix I, point III, 26, 27).

The recommendations asked for the involvement of the residents as well:

At the local level, participation by residents is an important component of housing, habitat and social regeneration schemes. Initiatives should be taken to support such participation by, for example by: 
- "promoting participation by residents and owners in the management, repair and renovation of their homes,

- giving support to the forming of residents' associations, e.g. through advice on their operation and management,

- supporting the establishment and running of national networks of local neighbourhood housing schemes in order to promote co-operation and to develop and share good practice" (ibid, Appendix I, point III, 44).

The recommendations demanded that the "Council of Europe's Congress of Local and Regional Authorities of Europe, in particular through the local and regional chambers of its Commission on Social Cohesion, should consider initiating activities on the local and regional aspects of housing policies " (ibid, Appendix I, point IX, 65).

\subsection{Other national, European and international activities}

Several international agreements which cover social and economic rights (European Human Rights Convention; the United Nations Covenant on Economic, Social and Cultural Rights; The United Nations Child's Rights Convention; European Social Charter, The European Revised and Improved Social Charter) recognise the right to housing and in relation to this, set certain obligations for the countries which are party to the agreements.

The UN Habitat Agenda (approved in Istanbul in 1996) recommends the member states to take measures to gradually guarantee the right to adequate housing (Art 61). The Habitat Agenda has set relatively extensive requirements for housing that is considered adequate, including sanitary conditions, safety, legal security of tenure, location, etc.

The European Social Charter (1966) guarantees housing for families (Art 16) and enough suitable subsidised housing. The European Revised and Improved Social Charter (1996) amended the Charter of 1966 adding as a new basic right the right to appropriate housing at reasonable prices. The Social Charter also provides, quite explicitly, the right to available housing which meets certain standards, the need to reduce homelessness and to make the price of housing accessible for persons with no adequate income. As the right to housing is relatively new in the Social Charter, there is no relevant case law today and therefore the level of standard expected from the countries is unclear. The European Council has recommended taking the standard provided in the UN Habitat Agenda as the basis for defining adequate housing. ${ }^{3}$

The European Union Agreement set social objectives for housing, including improvements, conditions and adequate social protection. However, there is no legal recourse at the European Union level for individuals if the measures in the housing sector are not applied. The housing measures are linked to issues tackled in the fight

3 For details compare Kährik et al. (2003: 3 ff). 
against social exclusion. The Union's strategic objectives set at the summit in Nice in December 2000 also verbalized measures that would ensure access to appropriate and sanitary housing and prevent social exclusion risks, including homelessness. These objectives were also taken into account in the Joint Inclusion Memorandum (JIM). The international agreements mentioned in the paragraph above also stipulate the right to adequate housing, though in the EU there is no minimal criteria set for housing conditions applicable to all member states. Thus, the European Council recommended taking the standards of the UN Habitat Agenda as the basis for defining adequate housing.

Many countries have included the right to housing in their constitution. All European countries have adopted the Universal Declaration of Human Rights and the International Covenant of Economic, Social, and Cultural Rights (respectively article 11), which include the right to housing.

An important step forward occurred in France ${ }^{4}$ when on January 4, 2007, the French Parliament adopted legislation guaranteeing the right to permanent housing, making France the second place in Europe - after Scotland - to adopt such a measure. The new law allows people to sue the government if they have no reliable place to live. Homeless people and those living in unsanitary or dangerous conditions will be able to take their plight to court from late 2008 onwards. Aside from aiding the homeless, the new law also benefits single mothers and impoverished workers. The right will be extended to other people, such as those in inadequate public housing, in 2012. Prime Minister Villepin also called for the construction of 120,000 housing units a year until 2012. Helping the homeless has become a major issue in the run-up to the presidential elections in April and May. ${ }^{5}$ After advocates drew attention to the plight of the homeless, the French government responded by pledging 100 million euros to help the country's most disadvantaged.

\subsection{Other relevant actors at the EU level}

In the field of housing and migrants' integration at the urban level, several other institutions are active at the European level. Their activities overlap partly with the programmes funded by the EU Commission listed above, as well as with national programmes or initiatives supported by the participating cities or local institutions.

4 About 8.5 million people in France have housing problems, according to a report issued by the Abbe Pierre Foundation. Of those, 1 million are living in temporary accommodation and 100,000 are sleeping on the streets (according to official figures from 2001, 86,500 people are homeless in France; aid groups say that more than 3 million have housing problems) (see Associated Press, 2007; Gehmlich, 2007).

5 Villepin said. "This is a principle that will place the right to housing on the same level as the right to medical care or education [...] It will make France one of the most progressive countries in the matter of social rights." 


\section{CECODHAS}

CECODHAS, a European network of social housing providers, is a nonprofit organization which represents its member organizations to European and international institutions and was founded 1988. The 46 full members of CECODHAS are national and regional housing organizations from 19 EU member states. Additionally, Switzerland and Norway are associate members. All members are nongovernmental, non profit organizations (www.cecodhas.org/).

Its key objectives are to promote the work of social housing organizations in the European Union, to foster the continuous exchange of ideas and experience among its members, to provide an information service for its members and to promote good practice through conferences, seminars, reports and other activities. It also aims to monitor developments in European Community law in order to reinforce the influence of CECODHAS in the debates on European policies, provide its members with improved access to European funding and campaign for the right to a decent home for all Europeans.

CECODHAS is structured into three sections and has three cross-sectional working groups. The working group on Urban Issues and Social Policies, especially, are relevant for the CLIP module on housing. In 2005, the latter formed a sub-group on housing and integration of migrants which organized a seminar in Stockholm in 2005. The subgroup is involved in the compilation of the second Handbook on Integration (DG JHA) by contributing case studies from the CECODHAS. It contributed to the first survey on quality of life (EuroFound 2004) by proposing items and is also contributing to the development of the questionnaire for the revised survey in 2006.

CECODHAS and its sub-group on housing and integration of migrants are particularly relevant for issues of social housing, its institutions, legal framework and practices within the first CLIP module on housing.

\section{CEMR}

The Council of European Municipalities and Regions (CEMR, founded in 1951) is an organisation of local and regional governments in Europe. It is an umbrella organization of 47 national associations of towns, municipalities and regions from 34 European countries, and is located in Brussels and Paris. The CEMR organizes the European section of the "United Cities and Local Governments" network (see: http://www.cities-localgovernments.org/), representing European cities. Within CEMR, the Working group on employment and social policy also deals with housing issues. The working group organises meetings of experts from the national organisations of cities and regions, facilitating the exchange of experiences and and promoting discussion of policy and project initiatives (see: http://www.ccre.org). The CEMR raised the issue of housing in its comments to the Commission's Green Paper on Demographic Change.

ENHR (European network for housing research)

The ENHR is a network on housing research bringing together academic researchers and practitioners which was established in 1988. Currently it has more then 1,000 
individual members and nearly 100 institutional members, representing every country in Europe. The purpose of the ENHR Working Groups is to further research on particular topics of housing research. Members of working groups usually come from a variety of academic disciplines and from different parts of Europe. There are two working groups that specialize on the issue of housing and migration: Migration, Residential Mobility and Housing Policy (Coordinators: Roland Goetgeluk and Maarten van Ham) and Housing and Minority Ethnic Groups (Coordinators: Gideon Bolt and Sule Özüekren; see: http://www.enhr.ibf.uu.se/wg.html).

\section{EUROCITIES}

EUROCITIES is a network of major European cities founded in 1986. The network aims to promote the sharing of knowledge and ideas, the exchange of experiences, the analysis of common problems, and the development of innovative solutions. It organizes forums, working groups, projects and conferences.

Within the social affairs forum, a working group on migration deals with questions of integration. The working group is chaired by the city of Rotterdam. In 2005 , EUROCITIES published political recommendations to national governments and EU institutions. In these recommendations, EUROCITIES members requested that the European Council and the Commission "should recognize the pivotal role of cities in the reception and integration process" and recommended that the Commission "develop a consultation framework with the large cities and their associations in Europe". Members of the Working Group on Migration come from the cities of Aarhus, Berlin, Københaven, Helsinki, Leeds, Leipzig, Malmø, Roma, Rotterdam, Southampton, Stockholm, Tampere, Turku, Utrecht, Vantaa and Vienna (see: http://www.eurocities.org/).

\section{Key concepts}

\subsection{The concept of integration}

There is still a lot of ambiguity in the way in which integration is defined. The term "integration" is employed in different contexts, including in socio-economic, legal, political or cultural contexts and dimensions of the integration process, which contributes to the variety of meanings associated with the term. A cross-national comparison indicates that the term has been given numerous different meanings with thus diverging political implications. Despite a lack of explicit definitions of integration, the term is used in different European countries in different ways, which can be polarized as follows:

1. integration as diversity in a multi-cultural society without any obligation of assimilation;

2. integration as a process of assimilation and perfect acculturation into the social class value system; 